\title{
Pengaruh Kejadian Bencana Alam dan Sosial Demografi Terhadap Kemiskinan di Jawa Tengah Tahun 2017-2020
}

(The Impact Of Natural Disasters And Socio Demographic On Poverty In Central Java 2017-2020)

\author{
Dinda Desinta ${ }^{1 *}$, Jeffry R. H. Sitorus ${ }^{2}$ \\ ${ }^{1,2}$ Politeknik Statistika STIS \\ Jl. Otto Iskandardinata No. 64C, Jatinegara, Jakarta Timur, 13330. \\ Email: 211709636@stis.ac.id
}

\begin{abstract}
ABSTRAK
Kemiskinan mengakibatkan seseorang tidak dapat memenuhi kebutuhan dasarnya sehingga tingkat kesejahteraan menurun. Pengentasan kemiskinan menjadi fokus yang ingin diraih oleh seluruh bangsa di dunia. Hal ini menjadi tujuan SDGs melalui target peniadaan kemiskinan (no poverty). Target ini juga tertuang dalam RPJMN 2015-2019 dan RPJMN 2020-2024. Provinsi Jawa Tengah menjadi provinsi kedua dengan jumlah penduduk miskin terbanyak di Indonesia dan memiliki persentase penduduk miskin yang lebih besar dari angka nasional. Tujuan penelitian ini adalah memberikan gambaran umum kemiskinan di Jawa Tengah tahun 2017-2020. Selanjutnya, metode analisis regresi data panel digunakan untuk mengetahui pengaruh faktor kejadian bencana alam dan sosial demografi terhadap kemiskinan. Hasil penelitian menunjukkan bahwa jumlah kejadian bencana tanah longsor, jumlah kejadian bencana gempa bumi, TPT, IPM dan persentase penduduk yang bekerja di sektor pertanian berpengaruh signifikan terhadap persentase penduduk miskin di Jawa Tengah tahun 2017-2020. Kesimpulannya bahwa untuk mengentaskan kemiskinan penduduk, perlu diperhatikan kesiapan dan kemampuan penduduk dalam menghadapi kejadian bencana alam yang mereka alami, serta perlu lebih ditingkatkan lagi kualitas kondisi sosial demografi penduduk di Jawa Tengah.
\end{abstract}

Kata kunci: kemiskinan, bencana alam, sosial demografi, regresi data panel

\begin{abstract}
Poverty causes people cannot meet their basic needs, so the prosperity decreases. Poverty alleviation becomes a focus that all countries in the world want to achieve. This becomes the purpose of SDGs through no poverty target. This target is also stated in RPJMN 2015-2019 and RPJMN 2020-2024. Central Java Province becomes the second province with the highest number of poverty in Indonesia and has a higher percentage of poor people than the national figure. This study aims to give a general description of poverty in Central Java Province in 2017-2020. Next, regression analysis of panel data method was used to find out the influence factors of natural disaster and socio-demography variables on poverty. The results of the study show that the number of landslides, earthquakes, open unemployment rate, human development index, and percentage of people who work in the agriculture sector significantly influence the poverty in Central Java in 2017-2020. The conclusion is that in order to improve the welfare of the population, it is necessary to pay attention to the readiness and ability of the population in dealing with the natural disasters, and to further improve the quality of the socio demography conditions of the population in Central Java Province.
\end{abstract}

Keywords: poverty, natural disaster, socio demography, regression of data panel

\section{PENDAHULUAN}

Kemiskinan merupakan masalah yang sangat krusial sebab ruang lingkupnya yang luas, dimana tidak hanya mencakup ruang lingkup ekonomi, tetapi mencakup juga permasalahan sosial demografi dan pengaruh kebencanaan yang menimpa suatu wilayah. Kemiskinan menyebabkan seseorang tidak dapat memenuhi kebutuhan dasarnya sehingga tingkat kesejahteraan menurun. Pengentasan kemiskinan menjadi salah satu prioritas yang ingin dicapai oleh semua negara di dunia. Hal ini menjadi tujuan Sustainable Development Goals (SDGs) melalui target peniadaan kemiskinan (no poverty). Rencana Pembangunan Jangka Menengah Nasional (RPJMN) periode 2015-2019 juga memperjelas tujuan SDGs ini melalui misi pemerataan pembangunan yang berkeadilan (salah satunya dengan peniadaan kemiskinan), dan dalam RPJMN 20202024 melalui penguatan ketahanan ekonomi untuk mencapai agenda keadilan dan kesejahteraan.

Berdasarkan data kemiskinan yang diperoleh dari Badan Pusat Statistik (BPS) tercatat jumlah penduduk miskin di Indonesia pada September 2019 mencapai 24,79 juta orang. Jika dibandingkan Maret 2019, jumlah penduduk miskin menurun 358,9 ribu orang. Sementara itu jika dibandingkan dengan September 2018, 
jumlah penduduk miskin menurun sebanyak 888,7 ribu orang. Persentase penduduk miskin pada September 2019 tercatat sebesar 9,22 persen, menurun 0,19 persen poin terhadap Maret 2019 dan menurun 0,44 persen poin terhadap September 2018 (BPS, 2019). Akan tetapi, justru pada tahun 2020 di Indonesia angka kemiskinan malah meningkat. Tercatat 27,55 juta orang hidup dalam kemiskinan pada September 2020, meningkat 1,13 juta orang dari Maret 2020 dan terjadi peningkatan kembali sebesar 1,63 juta orang dari September 2019. Pada September 2020, persentase orang miskin adalah 10,19 persen, naik 0,41 poin persentase dari Maret 2020 dan naik sebesar 0,97 poin persentase dari September 2019 (BPS, 2020).

Provinsi Jawa Tengah menjadi provinsi kedua dengan jumlah penduduk miskin terbanyak di Indonesia. Pada Maret 2020, 3,98 juta orang di Jawa Tengah diperkirakan hidup dalam kemiskinan. Jika dibuat perbandingan dengan September 2019, jumlah penduduk miskin meningkat 301,5 ribu orang. Sementara itu, jumlah penduduk miskin meningkat 237,67 ribu orang sejak Maret 2020. Dalam periode yang sama, Jawa Tengah secara konsisten memiliki persentase penduduk miskin yang lebih besar dari angka nasional (BPS, 2020). Capaian angka kemiskinan tersebut menyebabkan Provinsi Jawa tengah belum mampu memenuhi target capaian angka kemiskinan dalam Rencana Pembangunan Jangka Menengah Daerah (RPJMD). Padahal pengurangan kemiskinan merupakan salah satu visi pembangunan dalam RPJMD Jawa Tengah periode 2013-2018 dan 2018-2023.

Kemiskinan dapat berdampak pada setiap lini kehidupan. Ketika pada tingkatan individu, adanya kemiskinan menjadikan hilangnya kesempatan untuk mengenyam pendidikan atau kesempatan untuk mendapatkan pekerjaan yang mapan menjadi hilang. Mualifah (2019) menambahkan hilangnya sandang, pangan, dan papan menjadi dampak dari terjadinya kemiskinan di tingkat keluarga. Andrietya (2020) juga berpendapat bahwa kemiskinan dicirikan oleh masyarakat yang tidak mempunyai rumah yang layak bahkan sering digusur dari pemukimannya, demonstrasi yang biasa dilakukan ribuan pekerja, melakukan aksi protes dan melakukan pemutusan hubungan kerja (PHK), dan juga para pekerja yang diberi perlakukan yang seenaknya. Todaro \& Smith (2006) juga menambahkan kemiskinan yang hadir di tingkat nasional dapat menimbulkan disparitas pendapatan karena pertumbuhan ekonomi yang pesat tidak diikuti dengan pemerataan ekonomi yang berarti masyarakat miskin tidak diuntungkan. Jika kemiskinan tidak diperhatikan maka akan menyebabkan penduduk miskin tidak mampu dalam memenuhi kebutuhan dasarnya sehingga pada akhirnya penduduk miskin tersebut tidak memiliki kualitas diri yang baik dan tidak memiliki kompetensi yang diharapkan. Maka penduduk tersebut tidak bisa mengambil peran penting dalam pembangunan. Jika kemiskinan yang dialami terus berlanjut hingga penduduk miskin tersebut memiliki anak, selanjutnya anakanaknya tidak bisa mendapat pembekalan yang layak, sehingga saat memasuki usia kerja penduduk tersebut tidak berkompeten menjadi generasi penerus. Oleh karena itu, peneliti menganggap penting untuk melakukan penelitian dalam rangka pengentasan kemiskinan penduduk di Provinsi Jawa Tengah tahun 2017-2020.

Lal, et al. (2009) menyatakan bahwa salah satu penyebab utama kemiskinan adalah terjadinya bencana alam karena meningkatkan kerentanan orang miskin dan tingkat kemiskinan secara umum menjadi meningkat, sehingga rumah tangga akan terjebak di dalam lingkaran kemiskinan dan kemelaratan. Berdasarkan data yang dikutip dari Badan Nasional Penanggulangan Bencana Alam (BNPB), Indonesia berada pada pertemuan empat buah lempengan tektonik yang menyebabkan Indonesia memiliki tingginya potensi akan terjadinya bencana alam. Sabuk vulkanik (vulcanic arc) dapat ditemukan di wilayah selatan dan timur Indonesia, sedangkan wilayah lainnya terdiri dari pegunungan vulkanik tua dan dataran rendah yang didominasi oleh lahan basah. Karena faktor-faktor ini, sebagian besar wilayah Indonesia mengalami bencana alam seperti gunung meletus, gempa bumi, banjir, kekeringan, tsunami, dan tanah longsor.

Indonesia memiliki tingkat golongan yang tinggi akan terjadinya resiko bencana alam. Berdasarkan data baru yang dijadikan acuan, Indeks Resiko Bencana (IRB) tinggi terjadi hampir pada setiap provisi di Pulau Jawa (Gambar 1), untuk tingkatan IRB sedang hanya dimiliki oleh Provinsi DKI Jakarta dan D.I. Yogyakarta. Selanjutnya pada 2019, hanya DKI Jakarta yang memiliki IRB sedang, sehingga hampir semua provinsi di Pulau Jawa mempunyai risiko bencana tinggi, termasuk Provinsi Jawa Tengah sendiri.



Sumber: BNPB, diolah

Gambar 1. Peta IRB Indonesia tahun 2018 
Dalam World Risk Report 2019 yang diterbitkan oleh Bündnis Entwicklung Hilft and Institute for International Law of Peace and Armed Conflict (IFHV), Indonesia menduduki peringkat 37 dari 180 negara berdasarkan IRB. Sumber kemiskinan dapat terjadi karena adanya bercana alam, terutama untuk orangorang yang hidup di sekitar ambang kemiskinan khususnya. Sebagai akibat dari penghancuran aset orang miskin setelah peristiwa bencana, banyak keluarga yang berada dalam kondisi miskin karena mereka tidak memiliki sumber daya yang diperlukan untuk memperbaiki rumah mereka, mengganti harta benda mereka, dan memenuhi kebutuhan mereka. Akses sumber daya alam, aset fisik, modal manusia dan sumber daya keuangan juga penting bagi kemampuan masyarakat untuk menghadapi dan pulih dari bencana (Carney, 1998). Orang miskin di negara berkembang sangat rentan terhadap adanya dampak dan kerusakan yang diakibatkan oleh bencana alam (Bank Dunia dan Perserikatan Bangsa-Bangsa (PBB), (2010)). Hal yang menjadi penghalang utama pada proses pengurangan kemiskinan dan pengembangan fasilitas pembangunan ekonomi adalah karena adanya kerentanan pada bencana alam, membuat strategi tentang kesiapsiagaan atas bencana dan melaksanakan program perlindungan sosial sangat penting dalam melindungi orang miskin dari konsekuensi parah dari bencana alam dalam jangka panjang. Sawada (2017) menambahkan, kesejahteraan dari masyarakat bisa ditingkatkan secara permanen dengan kontribusi dari penerapan tindakan penanggulangan bencana

Dalam perekonomian nasional kelompok provinsi di Pulau Jawa menjadi penyumbang terbesar terhadap pergerakan perekonomian Indonesia termasuk Provinsi Jawa Tengah, namun Provinsi Jawa Tengah juga sangat rawan terhadap bencana alam dan isu sosial demografi lainnya. Jika terjadi kerusakan tentu akan berdampak negatif terhadap perekonomian. Maka dari itu perlu dilakukan tahap pra-bencana untuk mengurangi resiko dari dampak negative tersebut. (Twigg, 2004). Kasus pengangguran yang tinggi, pembangunan manusia, akses sanitasi, dan sektor pekerjaan penduduk merupakan faktor sosial demografi yang memengaruhi kemiskinan. Pengangguran dan kemiskinan memiliki hubungan yang erat dalam hal ini (Todaro \& Smith, 2006). Kemiskinan merupakan pendapatan yang menurun dan mengakibatkan kesejahteraan menurun karena bersumber pada suatu daerah yang memiliki tingkat pengangguran yang tinggi (Sukirno, 2004). Besarnya tingkat pengangguran dapat mencerminkan kurangnya keberhasilan suatu daerah dalam mengurangi kemiskinan, karena pengangguran memengaruhi kemiskinan dalam berbagai cara (Tambunan, 2001). Kualitas sumber daya manusia mampu menjadi faktor penunjang terjadinya kemiskinan, kualitas sumber daya manusia dapat dilihat dari IPM. Karena IPM yang rendah, penduduk akan kurang produktif, yang akan merusak kemampuan penduduk untuk memenuhi kebutuhan sehari-hari, dan hal tersebut membuat mereka mendapatkan perolehan pendapatan yang rendah sehingga semakin banyak penduduk miskin (Aldino, 2018).

Berdasarkan pemaparan tersebut dan dengan menggunakan ketersediaan data yang diperoleh, peneliti ingin mengetahui apakah dan bagaimana besarnya pengaruh faktor kejadian bencana alam dan sosial demografi terhadap pengentasan kemiskinan di Provinsi Jawa Tengah. Tujuan dari penelitian ini adalah untuk mengetahui gambaran umum mengenai kondisi kemiskinan, kejadian bencana alam dan sosial demografi di Jawa Tengah tahun 2017-2020 dan menganalisis pengaruh dari faktor kejadian bencana alam dan sosial demografi terhadap kemiskinan di Jawa Tengah tahun 2017-2020.

Pada penelitian sebelumnya oleh Rodriguez-Oreggia, et al. (2012), bencana alam (natural disaster) memiliki hubungan positif dan signifikan dengan tingkat kemiskinan. Studi ini juga menunjukkan bahwa guncangan di suatu wilayah dapat berdampak pada kemiskinan di wilayah tersebut, serta terjadinya banjir dan kekeringan juga memengaruhi secara signifikan terhadap kemiskinan. Bui, et al. (2014) menjelaskan yaitu ketimpangan dan kemiskinan dipengaurhi secara signifikan oleh bencana alam, dimana ketimpangan naik dan memperburuk kemiskinan karena adanya bencana alam. Disisi lain penelitian dari Aurori, et al. (2015) menunjukan terdapat korelasi negatif antara bencana alam dan kemiskinan, Pendapatan rumah tangga per kapita di daerah yang terkena bencana menjadi turun, dan hal ini berdampak pada pengeluaran yang menjadi menurun. Dapat disimpulkan, terdapat hubungan yang signifikan antara terjadinya bencana alam dan tingkat kemiskinan. Puspita (2015) menunjukkan bahwa tingkat kemiskinan memengaruhi secara positif dan signifikan kepada variabel pengangguran dan jumlah penduduk, sedangkan variabel PDRB berpengaruh negatif dan signifikan, tetapi angka melek huruf tidak berpengaruh signifikan terhadap angka kemiskinan sama sekali. Andrietya (2020), IPM dan PDRB berpengaruh negatif dan signifikan terhadap kemiskinan di Provinsi Jawa Tengah, sedangkan variabel investasi berpengaruh negatif dan signifikan terhadap kemiskinan.

Berdasarkan teori dan penelitian terdahulu, peneliti menduga bahwa faktor kejadian bencana alam dan sosial demografi memiliki pengaruh terhadap pengentasan kemiskinan di Provinsi Jawa Tengah. Berdasarkan teori dan penelitian terdahulu, peneliti menduga bahwa faktor kejadian bencana alam dan sosial demografi memiliki pengaruh terhadap pengentasan kemiskinan di Provinsi Jawa Tengah. Setelah 
mengetahui variabel-variabel yang memengaruhi secara signifikan terhadap pengentasan kemiskinan, hasil tersebut dapat dijadikan suatu kontribusi peneliti untuk stake holder dalam mengentaskan kemiskinan penduduk di Provinsi Jawa Tengah, sesuai dengan program pemerintah yang tertuang dalam RPJMN 20152019 dan RPJMN 2020-2024.

\section{METODE}

\section{Landasan Teori}

Kemiskinan merupakan permasalahan yang bersifat multidimensi sehingga memungkinkan untuk dikaji dalam berbagai sudut pandang. Menurut World Bank (2002) dimensi kemiskinan dapat dikelompokkan ke dalam empat hal mendasar, yaitu lack of opportunity, low capabilities, low level security and low capacity. Supriatna (1997) menyatakan bahwa keadaan yang serba terbatas namun bukan kehendak orang yang bersangkutan dapat disebut kemiskinan. Rendahnya tingkat pendidikan, produktivitas tenaga kerja, pendapatan, kesehatan dan gizi serta kehidupan dan kesejahteraan mereka yang menunjukkan ketidakberdayaan, inilah ciri-ciri penduduk miskin.

Sumber utama kemiskinan dapat disebabkan oleh bencana terutama bagi mereka yang hidup dekat dengan garis kemiskinan, menurut Carney (1998) perusakan aset masyarakat miskin dan masyarakat tidak miskin namun berada dekat dengan garis kemiskinan akan masuk ke dalam jebakan kemiskinan karena mereka kekurangan sumber daya yang diperlukan untuk membangun kembali rumah, mengganti aset dan memenuhi kebutuhannya kembali. Kemampuan masyarakat dalam pemenuhan kebutuhannya juga sangat bergantung pada akses sumber daya alam, modal manusia, aset fisik serta sumber keuangan atau pendapatan yang tersedia untuk masyarakat.

Definisi kemiskinan dikaji kembali dan diperluas berdasarkan permasalahan dan faktor yang menyebabkan penduduk disebut miskin. Definisi kemiskinan yang dikemukakan Chambers (1983) ialah suatu kesatuan konsep (integrated concept) yang memiliki lima dimensi, yaitu:

1. Kemiskinan (Poverty)

Ketidakmampuan penduduk dalam memenuhi kebutuhan pokok mengindikasikan kemiskinan. Konsep ini tidak hanya mengacu pada kelompok yang tidak memiliki pendapatan, akan tetapi dapat berlaku pula pada kelompok yang telah memiliki pendapatan namun belum mampu memenuhi kebutuhan hidupnya.

2. Ketidakberdayaan (Powerless)

Kekuatan sosial (social power) dari penduduk berkaitan erat dengan rendahnya pendapatan, terutama dalam memeroleh keadilan ataupun persamaan hak untuk mendapatkan penghidupan yang layak.

3. Kerentanan terhadap sanitasi darurat (State of Emergency)

Keadaan seseorang yang tidak memiliki kemampuan untuk menghadapi situasi yang tidak terduga dan membutuhkan alokasi pendanaan untuk mengatasinya, disebut miskin. Misalnya, situasi rentan terhadap bencana alam yang menyebabkan seseorang tidak dapat keluar dari zona kemiskinan.

4. Ketergantungan (Dependency)

Keterbatasan kemampuan dalam memenuhi kebutuhannya menyebabkan tingkat ketergantungan seseorang atau sekelompok orang terhadap pihak lain akan sangat tinggi. Bantuan yang didapat dari pihak lain sangat dibutuhkan terutama menyangkut dengan kebutuhan dan sumber pendapatan.

5. Keterasingan (Isolation)

Faktor lokasi menjadi salah satu yang menyebabkan seseorang atau sekelompok orang menjadi miskin. Penduduk yang berada jauh dari pusat-pusat pertumbuhan ekonomi pada umumnya akan dikatakan sebagai penduduk miskin. Dikarenakan umumnya sebagian besar fasilitas kesejahteraan berada di pusat perekonomian seperti perkotaan. Pada saat yang sama, masyarakat yang tinggal di daerah terpencil atau sulit dijangkau memiliki fasilitas sanitasi yang relatif buruk dan standar hidup rendah sehingga situasi ini yang menjadi latar belakang kemiskinan.

\section{Data dan Sumber Data}

Berdasarkan uraian sebelumnya, peneliti membatasi variabel independen yang digunakan, yaitu faktor kejadian bencana alam: jumlah kejadian bencana banjir $\left(X_{1}\right)$, jumlah kejadian bencana tanah longsor $\left(\mathrm{X}_{2}\right)$, jumlah kejadian bencana gempa bumi $\left(\mathrm{X}_{3}\right)$, dan faktor sosial demografi: Tingkat Pengangguran Terbuka (TPT) $\left(\mathrm{X}_{4}\right)$, Indeks Pembangunan Manusia (IPM) $\left(\mathrm{X}_{5}\right)$, dan persentase penduduk yang bekerja di sektor pertanian $\left(\mathrm{X}_{6}\right)$, sementara variabel dependen yang digunakan ialah persentase penduduk miskin. Selanjutnya, dengan menggunakan ketersediaan data variabel-variabel tersebut yang dapat diperoleh dari BPS dan BNPB, peneliti ingin mengetahui apakah dan bagaimana besarnya pengaruh kejadian bencana alam dan sosial 
demografi terhadap pengentasan kemiskinan di Provinsi Jawa Tengah. Data yang digunakan merupakan data cross section dari 35 kabupaten/kota di Provinsi Jawa Tengah yang diamati dalam kurun waktu 4 (empat) tahun dengan periode 2017-2020.

\section{Metode Analisis}

Metode analisis yang digunakan dalam penelitian ini yaitu analisis deskriptif bertujuan untuk menjelaskan gambaran umum mengenai persentase penduduk miskin, faktor kejadian bencana alam dan sosial demografi di Provinsi Jawa Tengah tahun 2017-2020. Analisis inferensia pada penelitian ini menggunakan analisis regresi data panel yang mampu menggabungkan data cross section dengan data time series (Baltagi, 2005). Analisis inferensia bertujuan untuk mengetahui seberapa besar pengaruh faktor kejadian bencana alam dan sosial demografi terhadap persentase penduduk miskin di Provinsi Jawa Tengah tahun 2017-2020. Model regresi data panel yang digunakan sebagai berikut:

$$
\begin{gathered}
\text { PERSENMISKIN } i t=\alpha+\beta_{1} \text { BANJIR }_{i t}+\beta_{2} \text { LONGSOR }_{i t}+\beta_{3} \text { GEMPA }_{i t}+ \\
\beta_{4} \text { TPT }_{i t}+\beta_{5} \text { IPM }_{i t}+\beta_{6} \text { PERTANIAN }_{i t}+u_{i t}
\end{gathered}
$$

Keterangan:

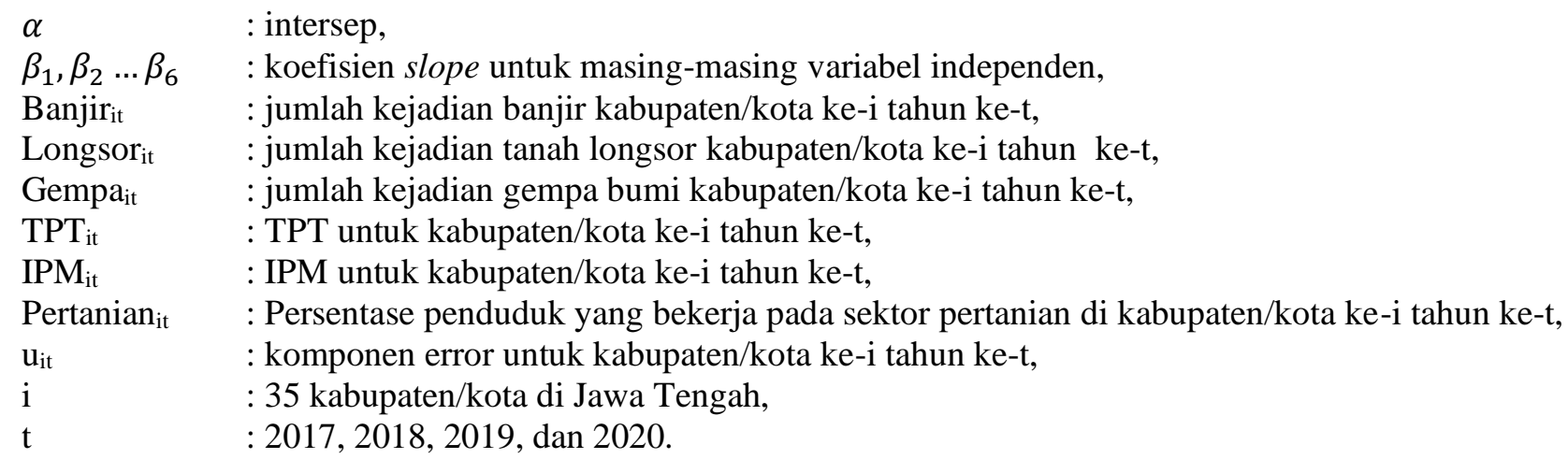

\section{HASIL DAN PEMBAHASAN}

\section{Gambaran Umum Kemiskinan, Kejadian Bencana Alam dan Sosial Demografi di Jawa Tengah}

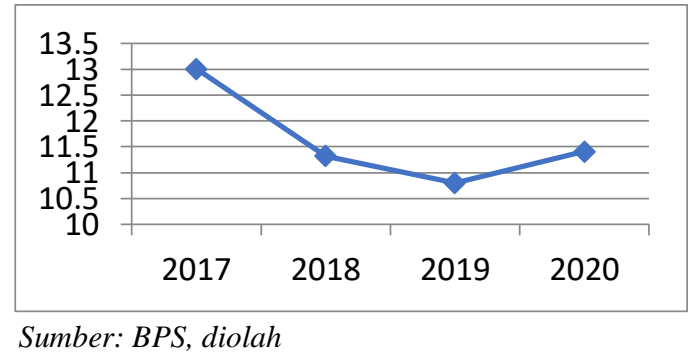

Gambar 2. Persentase Penduduk Miskin di Provinsi Jawa Tengah 2017-2020

Gambar 2. menunjukkan bahwa di tahun 2017 persentase penduduk miskin di Provinsi Jawa Tengah adalah sebesar 13,01 persen. Kemudian, turun menjadi 11,32 persen di tahun 2018, serta mengalami penurunan kembali di tahun 2019 menjadi 10,8 persen. Namun, di tahun 2020 persentase penduduk miskin di Provinsi Jawa Tengah mengalami peningkatan yang cukup tinggi, dimana persentase penduduk miskin berada di angka 11,41 persen. Peningkatan persentase penduduk miskin pada tahun 2020 terjadi karena adanya pandemi Covid-19 sepanjang tahun 2020, yang menyebabkan pertumbuhan ekonomi di Provinsi Jawa Tengah mengalami kontraksi dan meningkatkan persentase penduduk miskin (BPS, 2020). 


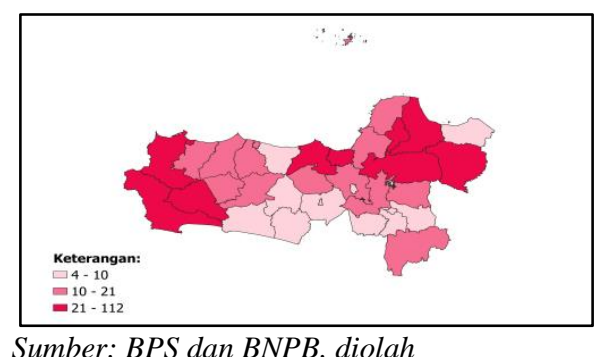

Gambar 3. Peta sebaran kejadian banjir di Jawa Tengah 2017-2020

Pada Gambar 3. terlihat bahwa persebaran kejadian bencana banjir di tahun 2017-2020 pada kabupaten/kota di Jawa Tengah pada kuantil terkecil dengan jumlah kejadian banjir sebanyak 4-10 kejadian berada di dua belas kabupaten/kota di Provinsi Jawa Tengah, dan kejadian bencana yang terletak pada kuantil terbesar dengan jumlah kejadian banjir lebih dari $21 \mathrm{kali}$, berada pada sepuluh kabupaten/kota, serta sisanya berada pada rentang kejadian bencana banjir sebanyak 10-21 kali. Jumlah kejadian banjir terbanyak yang terjadi pada tahun 2017-2020 berada di Kota Semarang dengan 112 kejadian. Berdasarkan peta tematik terlihat bahwa wilayah dengan kejadian banjir lebih tinggi cenderung berada di wilayah dataran rendah.

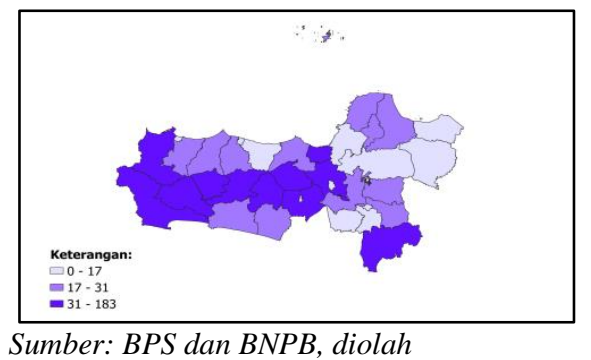

Gambar 4. Peta sebaran kejadian tanah longsor di Jawa Tengah 2017-2020

Gambar 4. menunjukkan bahwa persebaran kejadian bencana tanah longsor kabupaten/kota di Jawa Tengah tahun 2017-2020 pada kuantil terkecil dengan jumlah kejadian tanah longsor sebanyak 1-17 kejadian berada di dua belas kabupaten/kota di Provinsi Jawa Tengah, dan kejadian bencana yang terletak pada kuantil terbesar dengan jumlah kejadian tanah longsor lebih dari 31 kali, berada pada sepuluh kabupaten/kota, serta sisanya berada pada rentang kejadian bencana tanah longsor sebanyak 17-31 kali. Jumlah kejadian banjir terbanyak yang terjadi pada tahun 2017-2020 berada di Kota Semarang dengan 183 kejadian. Peta tematik menunjukkan bahwa wilayah yang sering terjadi tanah longsor mengelompok dan berada ditengah, dimana daerah tersebut cenderung menunjukkan daerah pegunungan.

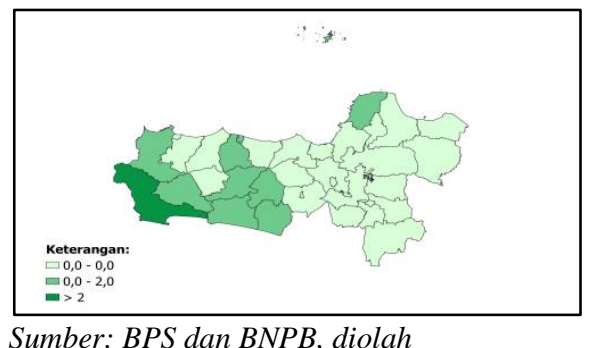

Gambar 5. Peta sebaran kejadian gempa bumi di Jawa Tengah 2017-2020

Gambar 5. menunjukkan bahwa sepuluh kabupaten/kota di Jawa Tengah mengalami kejadian gempa bumi pada periode tahun 2017-2020, sedangkan kabupaten/kota lainnya tidak mengalami kejadian gempa bumi pada periode tahun 2017-2020. Kabupaten Cilacap merupakan kabupaten dengan kejadian bencana gempa bumi terbanyak dibandingkan kabupaten/kota lainnya di Jawa Tengah. Kabupaten Cilacap berada dekat dengan jalur sesar Pamanukan-Cilacap serta wilayah ini berhadapan langsung dengan zona subduksi antara Lempeng Indo-Australia dan Lempeng Eurasia, hal tersebut yang menyebabkan Kabupaten Cilacap rawan terjadi kejadian gempa bumi. 


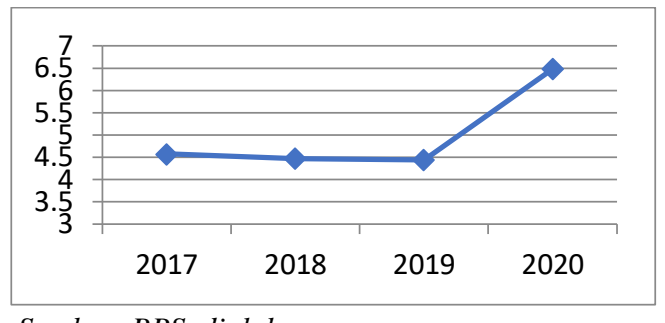

Sumber: BPS, diolah

Gambar 6. TPT di Jawa Tengah 2017-2020

Pada Gambar 6. terlihat bahwa TPT di Provinsi Jawa Tengah cenderung menurun dari tahun 2017 hingga 2019. Hal tersebut menunjukkan bahwa lapangan pekerjaan semakin mampu dalam menyerap angkatan kerja yang ada di Provinsi Jawa Tengah. Namun, TPT di Provinsi Jawa Tengah ini mengalami peningkatan pada tahun 2020. Peningkatan pengangguran di Jawa Tengah terjadi karena akibat dari pandemi Covid-19 yang berdampak pada stabilitas pasar tenaga kerja. Menurut BPS (2020), pandemi Covid-19 menyebabkan penurunan lowongan pekerjaan di Jawa Tengah. Jumlah iklan lowongan kerja pada April 2020 menurun 39,76 persen dibandingkan bulan sebelumnya. Sehingga, 377 ribu penduduk usia kerja menjadi menganggur akibat dari pandemi Covid-19.

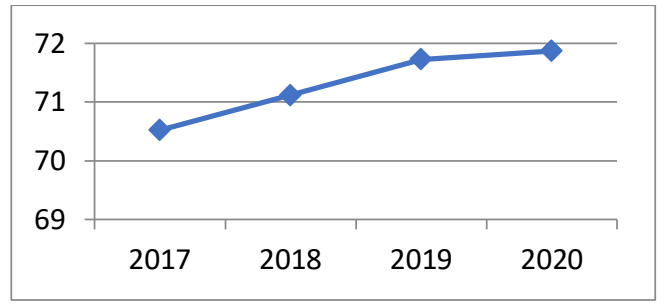

Sumber: BPS, diolah

Gambar 7. IPM di Jawa Tengah 2017-2020

Gambar 7. menunjukkan bahwa IPM Provinsi Jawa Tengah periode 2017-2020 mengalami peningkatan. Selama periode penelitian, nilai IPM Provinsi Jawa Tengah berada diatas 70 , berdasarkan klasifikasi IPM oleh UNDP (1990) nilai IPM yang berada pada interval 66 hingga 80 tergolong berada pada kategori menengah atas. Dengan begitu dapat dikatakan bahwa secara umum, kualitas sumber daya manusia di Provinsi Jawa Tengah sudah baik dan semakin membaik dari tahun ke tahun. Peningkatan IPM juga dapat menunjukkan bahwa kinerja pemerintah cukup baik dalam meningkatkan kesejahteraan dan kualitas sumber daya manusia pada masyarakat di Provinsi Jawa Tengah periode 2017-2020.

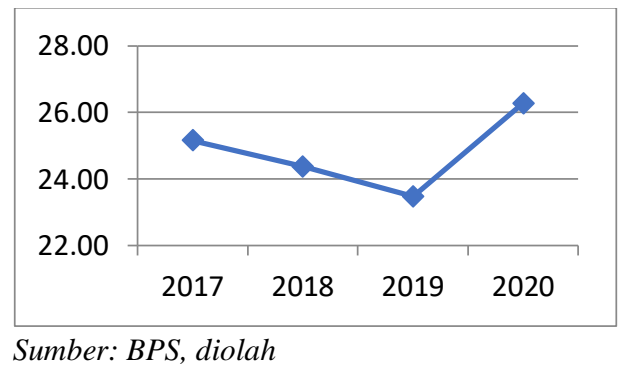

Gambar 8. Persentase penduduk yang bekerja pada sektor pertanian di Jawa Tengah 2017-2020

Profil keluarga miskin di Indonesia seringkali melekat pada penduduk yang bekerja di sektor pertanian (BPS, 2013). Penduduk yang bekerja pada sektor pertanian di Provinsi Jawa Tengah mengalami peningkatan yang cukup tinggi pada tahun 2020 (Gambar 8), salah satu penyebab peningkatan tersebut ialah adanya peralihan tenaga kerja sektor industri dan konstruksi yang menurun akibat pandemi Covid-19. Penyebab lain yang berdampak pada peningkatan persentase penduduk yang bekerja di sektor pertanian ialah karena didorong oleh produksi pada subsektor tanaman pangan dan hortikultura.

\section{Pengaruh Kejadian Bencana Alam dan Sosial Demografi Terhadap Kemiskinan di Jawa Tengah Tahun 2017-2020}

Pemilihan model terbaik menggunakan uji Chow menghasilkan $p$-value kurang dari alpha $(0,05)$ yaitu sebesar 0,0000 sehingga keputusan yang diambil adalah tolak $\mathrm{H}_{0}$. Dapat disimpulkan bahwa FEM lebih tepat digunakan dibandingkan dengan CEM. Pengujian selanjutnya yaitu uji Hausman yang menghasilkan $p$-value 
kurang dari alpha $(0,05)$ yaitu sebesar 0,0001 sehingga keputusan yang yang diambil adalah tolak $\mathrm{H}_{0}$. Maka kesimpulan yang diperoleh yaitu FEM lebih tepat digunakan dibandingkan dengan REM.

Selanjutnya dilakukan pengujian struktur matriks varian-kovarians matriks residual. Pengujian asumsi homoskedastis dilakukan dengan uji Lagrange Multiplier (LM) memperoleh keputusan akhir tolak $\mathrm{H}_{0}$ sehingga dapat disimpulkan bahwa struktur matriks varians-kovarians residual bersifat heteroskedastis. Sedangkan cross-sectional correlation diuji dengan uji $\lambda L M$ dan diperoleh kesimpulan bahwa terdapat crosssectional correlation. Dari dua pengujian maka metode estimasi yang tepat digunakan adalah Feasible Generalized Least Square-Seemingly Unrelated Regression (FGLS - SUR).

Pengujian asumsi klasik meliputi asumsi normalitas dan non-multikolinieritas. Pengujian normalitas dengan Kolmogorov-Smirnov memperoleh keputusan gagal tolak $\mathrm{H}_{0}$. Sehingga dapat disimpulkan bahwa residual berdistribusi normal. Pada pengujian asumsi nonmultikolinearitas, tidak terdapat variabel independen yang memiliki nilai VIF diatas 10. Hasil ini menunjukkan bahwa tidak terdapat multikolinearitas antarvariabel independen sehingga asumsi nonmultikolinearitas terpenuhi.

Tabel 1. Ringkasan Hasil Estimasi Model Regresi Data Panel

\begin{tabular}{|c|c|c|c|}
\hline Variable & Coefficient & Standard Error & t-Statistic \\
\hline$(1)$ & $(2)$ & (3) & $(4)$ \\
\hline $\mathrm{C}$ & 91,39738 & 12,02142 & $7,602875^{*}$ \\
\hline Banjir & $-0,007736$ & 0,005594 & $-1,382965$ \\
\hline Longsor & 0,015704 & 0,005978 & $2,626885^{*}$ \\
\hline Gempa & 0,983508 & 0,126941 & $7,747790^{*}$ \\
\hline TPT & 0,263320 & 0,045227 & $5,822132^{*}$ \\
\hline IPM & $-1,148339$ & 0,164932 & $-6,962507^{*}$ \\
\hline Pertanian & 0,041312 & 0,016964 & $2,435317^{*}$ \\
\hline \multicolumn{4}{|c|}{ Goodness of Fit (GoF) } \\
\hline$R$-Squared & 0,992934 & $F$-Statistic & 347,7836 \\
\hline Adj R-Squared & 0,990079 & Prob (F-Statistic) & 0,0000 \\
\hline
\end{tabular}

Sumber: BPS, diolah

Berdasarkan tahapan pengujian yang dilakukan sebelumnya, model yang terpilih adalah Fixed Effect Model (FEM) dengan metode estimasi Seemingly Unrelated Regression (SUR). Hasil model yang didapat adalah sebagai berikut:

$$
\begin{aligned}
\text { PERS } \widehat{E N M I S K I N ~} & \left(91,3973+u_{i}\right)^{*}-0,0077(\text { BANJIR })+0,01577(\text { LONGSOR })^{*}+0,9835(\text { GEMPA })^{*}+ \\
& 0,2633(\text { TPT })^{*}-1,1483(\text { IPM })^{*}+0,0413(\text { PERTANIAN })^{*}
\end{aligned}
$$

Keterangan:

*) signifikan pada tingkat signifikansi 5\%

Berdasarkan tabel 1 hasil uji $\mathrm{F}$ memeroleh keputusan tolak $\mathrm{H}_{0}$, maka dapat disimpulkan bahwa terdapat minimal satu variabel independen dalam model yang secara signifikan memengaruhi variabel persentase penduduk miskin.

Nilai $t$-statstic pada tabel 1 untuk variabel jumlah kejadian bencana tanah longsor, jumlah kejadian bencana gempa bumi, TPT, dan persentase penduduk yang bekerja pada sektor pertanian memiliki nilai yang lebih besar daripada tabel $(1,660391)$. Maka dapat dikatakan bahwa variabel tersebut berpengaruh positif dan signifikan terhadap persentase penduduk miskin. Variabel IPM memiliki nilai yang lebih kecil dibandingkan $t_{\text {tabel }}(-1,660391)$ sehingga dapat disimpulkan bahwa IPM berpengaruh negatif dan signifikan terhadap persentase penduduk miskin. Sementara, variabel jumlah kejadian bencana banjir tidak signifikan memengaruhi persentase penduduk miskin.

Nilai adjusted $R$-squared yang ditunjukkan pada tabel 1 yaitu sebesar 0,9901 . Hasil ini menunjukkan bahwa variabel independen yang digunakan pada penelitian mampu menjelaskan variasi variabel dependen sebesar 99,01\% sedangkan 0,99\% sisanya dijelaskan oleh variabel lain yang tidak tercakup dalam model.

Dari model terbaik yang telah terbentuk, diperoleh hasil bahwa variabel jumlah kejadian bencana tanah longsor, jumlah kejadian bencana gempa bumi, tingkat pengangguran terbuka, dan persentase penduduk yang bekerja pada sektor pertanian memiliki pengaruh positif dan signifikan terhadap persentase penduduk miskin. Sedangkan, variabel indeks pembangunan manusia memiliki pengaruh negatif dan signifikan, serta variabel jumlah kejadian bencana banjir tidak signifikan memengaruhi persentase penduduk miskin kabupaten/kota di Provinsi Jawa Tengah periode 2017-2020. 
Hasil estimasi pada persamaan (2) menunjukkan koefisien variabel jumlah kejadian bencana tanah longsor adalah 0,015704. Angka tersebut menunjukkan bahwa setiap terjadi tambahan 1 kejadian bencana tanah longsor maka akan menambah persentase penduduk miskin sebesar 0,0157 dengan asumsi variabel lainnya konstan (ceteris paribus). Hasil tersebut sejalan dengan penelitianyang dilakukan Noy (2009) bahwa bencana alam menciptakan keadaan darurat, mengancam kehidupan manusia, kematian, penyebaran penyakit, gagal panen, kerusakan alam dan sarana prasarana, melemahkan kelembagaan dan gangguan ekonomi hingga gangguan terhadap aktivitas sosial dapat disebabkan oleh bencana alam. Isa (2016) menyebutkan bahwa bencana alam yang terjadi di Provinsi Jawa Tengah berpengaruh positif baik secara langsung ataupun tidak langsung terhadap perekonomian yang terjadi di provinsi tersebut.

Koefisien variabel jumlah kejadian bencana gempa bumi yang ditunjukkan pada persamaan (2) sebesar 0,983508. Nilai ini menunjukkan bahwa setiap penambahan 1 kejadian bencana gempa bumi akan meningkatkan persentase penduduk miskin sebesar 0,983 dengan asumsi variabel lainnya konstan. Menurut Aliyu, et al. (2014) bahwa bencana alam seperti gempa bumi dan angin topan mampu menghancurkan prasarana dan perumahan serta berdampak pada korban jiwa yang terluka dan meninggal, serta memberikan pengaruh kuat dalam mengancam kehidupan dan penghidupan. Silbert \& Useche (2011) mengungkapkan bahwa dampak dari bencana alam bersifat langsung dan signifikan memengaruhi kemiskinan, serta dampak dari ketidakmampuan memenuhi kebutuhan konsumsi yang disebabkan oleh guncangan bencana alam ini mampu menyebabkan penduduk yang berada dekat dengan garis kemiskinan jatuh miskin.

Hasil estimasi menunjukkan koefisien variabel TPT sebesar 0,26332. Hal ini berarti setiap kenaikan 1 persen TPT akan meningkatkan persentase penduduk miskin sebesar 0,26332\% dengan asumsi variabel lainnya konstan. Retnowati \& Harsuti (2016) mengungkapkan bahwa saat penduduk menganggur maka akan mengurangi pendapatan, sehingga tingkat kemakmuran yang dicapai otomatis menurun dan cenderung akan mengurangi secara paksa kebutuhannya. Ningrum (2017) membuktikan bahwa TPT berpengaruh signifikan positif terhadap kemiskinan disebabkan karena seorang pengangguran tentunya tidak memiliki penghasilan dari pekerjaan. Kebutuhan penduduk yang tinggi dan beragam mengharuskan mereka bekerja dengan keras untuk memenuhinya. Jika tidak bekerja maka mereka tidak mampu mencukupi kebutuhannya secara baik, dampaknya mereka akan menjadi miskin dan meningkatkan kemiskinan yang ada.

Koefisien variabel IPM sebesar-1,148339. Nilai ini menunjukkan bahwa kenaikan 1 persen IPM akan menurunkan persentase kemiskinan sebesar 1,149339\% dengan asumsi variabel lainnya konstan (ceteris paribus). Aldino (2018) menyebutkan bahwa IPM semakin membaik disuatu daerah maka mampu memberikan sumber daya manusia yang semakin berkualitas sehingga mampu menurunkan kemiskinan pada dearah tersebut. Ningrum (2017) pada penelitiannya menunjukkan bahwa IPM mengakibatkan naiknya produktifitas sehingga mampu menaikkan penghasilan penduduk dengan meningkatkan pendapatan maka kemampuan penduduk untuk untuk mencukupi kebutuhannya juga meningkat.

Hasil estimasi menunjukkan koefisien variabel persentase penduduk yang bekerja di sektor pertanian sebesar 0,041312. Nilai ini berarti pada kenaikan 1 persen penduduk yang bekerja di sektor pertanian akan meningkatkan persentase penduduk miskin sebesar $0,041312 \%$ dengan asumsi variabel lainnya konstan. Satrio (2018) menunjukkan bahwa pertanian sebagai mata pencaharian penduduk mengindikasikan meningkatkan risiko kemungkinan kemiskinan dibandingkan dengan penduduk yang bekerja di sektor selain pertanian. World Bank (2007) menyatakan bahwa kemiskinan sebagai dampak dari penduduk yang mayoritas bekerja di bidang pertanian memiliki hubungan yang sangat kuat. Dikarenakan tingkat konsumsi yang rendah dibandingkan dengan pekerjaan selain disektor pertanian.

Hasil estimasi menggunakan Fixed Effect Model SUR memberikan nilai cross section effect (efek individu). Nilai ini merupakan cerminan dari variabel yang tidak tercakup dalam model tetapi berpengaruh terhadap perbedaan karakteristik individu, penelitian ini efek individunya adalah kabupaten/kota. Hasil menunjukkan bahwa efek individu paling tinggi ditunjukkan oleh Kota Salatiga sebesar 6,823373. Sedangkan efek individu paling kecil ditunjukkan oleh Kabupaten Tegal sebesar -8,431648.

\section{KESIMPULAN}

Persentase penduduk miskin, TPT dan persentase penduduk yang bekerja di sektor pertanian di Provinsi Jawa Tengah mengalami penurunan pada periode 2017-2019 namun mengalami peningkatan di tahun 2020. Kejadian bencana banjir dan tanah longsor terjadi diseluruh kabupaten/kota di Jawa Tengah, sedangkan kejadian gempa bumi terjadi di sebagian kabupaten/kota di Jawa Tengah. Sementara, IPM mengalami peningkatan pada setiap tahunnya.

Hasil analisis menunjukkan bahwa jumlah kejadian bencana banjir, tanah longsor dan gempa bumi, TPT, IPM dan persentase penduduk bekerja di sektor pertanian, secara simultan berpengaruh signifikan terhadap persentase penduduk miskin. Secara parsial, jumlah kejadian bencana tanah longsor, jumlah 
kejadian bencana gempa bumi, TPT, IPM dan persentase penduduk bekerja pada sektor pertanian berpengaruh signifikan terhadap persentase penduduk miskin.

Dapat disimpulkan bahwa untuk meningkatkan kesejahteraan penduduk di Provinsi Jawa Tengah, dalam hal mengupayakan semakin berkurangnya jumlah penduduk miskin, perlu diperhatikan kesiapan dan kemampuan penduduk dalam menghadapi kejadian bencana alam yang menimpa mereka, selain itu perlu lebih ditingkatkan lagi kualitas kondisi sosial demografi penduduk di Jawa Tengah.

\section{DAFTAR PUSTAKA}

Aldino, Moch. 2018. Analisis Kemiskinan di Jawa Tengah. Yogyakarta: Universitas Islam Indonesia.

Andrietya, Achyarnis Lilik. 2020. Determinan Kemiskinan Di Provinsi Jawa Tengah. Universitas Negeri Semarang.

Arouri, Mohamed., Youssef, Adel Ben., \& Nguyen, Cuong. 2015. Natural Disasters, Household Welfare, and Resilience: Evidence from Rural Vietnam. HAL Archives-Ouvertes: France.

Badan Nasional Penanggulangan Bencana. 2018. Indeks Risiko Bencana Indonesia. Jakarta.

Badan Pusat Statistik. 2019. Profil Kemiskinan di Indonesia September 2019. Jakarta.

Badan Pusat Statistik. 2020. Profil Kemiskinan di Indonesia September 2020. Jakarta.

Baltagi, Badi H. 2005. Econometric Analysis of Panel Data 3rd Edition. West Sussex: John Wiley \& Sons.

Bui, Anh Tuan., Dungey, Mardi., Nguyen, Cuong Viet., \& Pham, Thu Phuong. 2014. The Impact of Natural Disaster on Household Income, Expenditure, Poverty and Inequality: Evidence from Vietnam. ResaerchGate.

Carney, Diana. 1998. Implementing the Sustainable Rural Livelihoods Approach. Department for International Development. London: UK.

Chambers, Robert. 1983. Rural Development: Putting the Last First. USA: British Library Cataloguing.

IFHV. 2019. World Risk Report 2019. Druckerei Conrad: Berlin.

Kementrian PPN/Bappenas. 2020. Pedoman Teknis Penyusunan Rencana Aksi Edisi II Tujuan Pembangunan Berkelanjutan/Sustainable Development Goals (TPB/SDGs). Jakarta.

Lal, Padma N., Singh, Reshika., \& Holland, Paula. 2009. Relationship Between Natural Disaster and Poverty: A Fiji Case Study. SOPAC.

Mualifah, Nur. 2019. Dampak Kemiskinan terhadap Kesejahteraan Masyarakat Kampung Bumi Raharjo dalam Prespektif Ekonomi Islam. IAIN Metro.

Pemerintah Provinsi Jawa Tengah. 2014. Rencana Pembangunan Jangka Menengah Daerah (RPJMD) Provinsi Jawa Tengah Tahun 2013-2018. Jawa Tengah.

Pemerintah Provinsi Jawa Tengah. 2019. Rencana Pembangunan Jangka Menengah Daerah (RPJMD) Provinsi Jawa Tengah Tahun 2018-2023. Jawa Tengah.

Puspita, Dita Wahyu. 2015. Analisis Determinan Kemiskinan Di Provinsi Jawa Tengah. Universitas Negeri Semarang.

Rodriguez-Oreggia, Eduardo., Fuente, Alejandro de la., Torre, Rodolfo de la., \& Moreno, Hector A. 2012. Natural Disaster, Human Development, and Poverty at the Municipal Level in Mexico. Journal of Development Studies: Taylor and Francis.

Sawada, Yasuyuki., \& Takasaki, Yoshito. 2017. Natural Disaster, Poverty and Development. University of Tokyo: Japan.

Sukirno, Sadono. 2004. Pengantar Teori Makroekonomi. Jakarta: PT. Raja Grafindo Persada.

Supriatna, Tjahya. (1997). Birokrasi Pemberdayaan Dan Pengentasan Kemiskinan. Bandung: Humaniora Utama Press.

Tambunan, Tulus H. 2001. Perekonomian Indonesia. Jakarta: Ghalia.

Todaro, Michael P., \& Smith, Stephen C. 2006. Economic Development 12th Edition. New York: Pearson.

Twigg, Jhon. 2004. Disaster Risk Reduction Mitigation and Preparedness in Development and Emergency Programming. London: UK. 